\title{
Design of a TENS knee pad with integrated textile electrodes DOI: 10.35530/IT.072.03.1700
}

\section{ABSTRACT - REZUMAT}

\section{Design of a TENS knee pad with integrated textile electrodes}

Transcutaneous electrical nerve stimulation (TENS) is defined as the application of electrical current to the skin for pain control by the American Physical Therapy Association (APTA). The TENS treatment is extensively preferred since it is safe, not expensive and has no side effects when compared to drug therapy. TENS therapy is applied using clinical or portable type TENS devices and TENS electrodes. However, conventional electrodes are not hygienic because they are not washable and their sticky structure makes patients uncomfortable. Furthermore, they are not suitable to be integrated into a smart garment. In this study, a knee pad with integrated electrodes and textile transmission lines have been designed and developed to be used for TENS therapy. Electrical resistance values of textile electrodes and transmission lines which are integrated into the knee pad were measured. The developed knee pad was connected to a commercially available TENS device and electrical current transmission on subjects was tested. Furthermore, washing tests were conducted on the knee pad.

Keywords: electronic textiles, smart garment, conductive yarns, conductive materials

\section{Proiectarea unei genunchiere TENS cu electrozi textili integrați}

Stimularea electrică a nervului transcutanat (TENS) este definită de către Asociația Americană de Terapie Fizică (APTA) ca aplicarea curentului electric pe piele pentru controlul durerii. Tratamentul TENS este preferat pe scară largă, deoarece este sigur, nu este scump și nu are efecte secundare în comparație cu terapia medicamentoasă. Terapia TENS se aplică utilizând dispozitive TENS clinice sau portabile și electrozi TENS. Cu toate acestea, electrozii convenționali nu sunt igienici, deoarece nu sunt lavabili și structura lor nu le oferă confort pacienților. În plus, aceștia nu sunt potriviți pentru a fi integrați în îmbrăcămintea inteligentă. În acest studiu, o genunchieră cu electrozi și linii de transmisie integrate în materialul textil a fost proiectată și dezvoltată pentru a fi utilizată pentru terapia TENS. Au fost măsurate valorile rezistenței electrice ale electrozilor și liniilor de transmisie care sunt integrate în genunchieră. Genunchiera dezvoltată a fost conectată la un dispozitiv T́ENS disponibil comercial și a fost testată transmisia de curent electric pe subiecți. Mai mult, s-au efectuat teste de spălare pentru genunchieră.

Cuvinte-cheie: textile electronice, îmbrăcăminte inteligentă, fire conductive, materiale conductive

\section{INTRODUCTION}

Transcutaneous electrical nerve stimulation (TENS), one of the electrical pain treatments, is defined as the application of electrical current to the skin for pain control by the American Physical Therapy Association (APTA) [1]. In TENS treatment, all or some of the sensory, motor, sensory-motor-nociceptive nerve fibers are stimulated using electrodes to influence the neuro-hormonal, neuro-physiological and cognitive system. TENS treatments are based on different action mechanisms however the most commonly used one is the "Gate Control Theory" which was introduced by Melzack and Wall in 1965 [2]. According to this theory, substantia gelatinosa acts as a gate control system that modulates the synaptic transmission of nerve impulses from peripheral fibers to central cells. A schematic diagram of the gate control theory in pain mechanisms is given in figure 1 [3]. The fundamental indications of TENS treatment are acute and chronic pain syndromes. It is known that TENS therapy, which was tested and still being tested by many researchers, is used in cases such as rheumatoid arthritis, osteoarthritis, low back pain, neck pain, neuropathic pain, labor pain, dysmenorrhea, after multiple rib fractures and so on [2]. The effect of TENS treatment varies depending on the source of the pain, the pain threshold of the individual, the electrode location, the intensity of stimulation

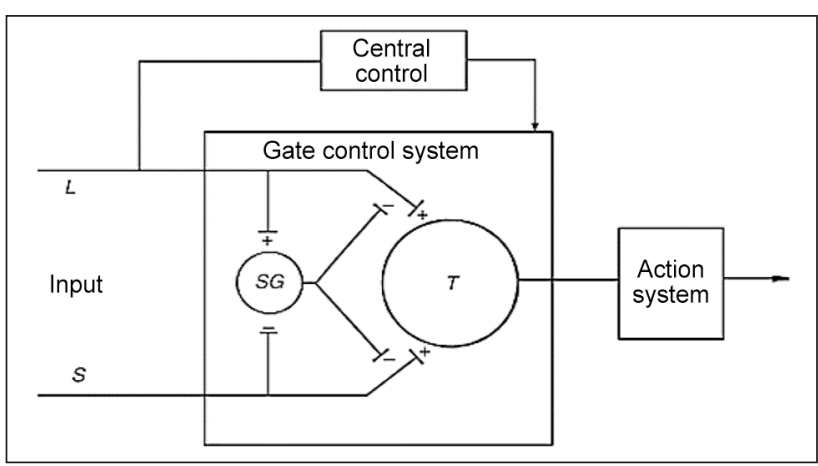

Fig. 1. A schematic diagram of the gate control theory in pain mechanisms: $L$ - the large-diameter fibers; $S$ - the small-diameter fibers; $S G$ - substantia gelatinosa; $T$ - transmission cells; + excitation; - inhibition [3] 
and the electrical characteristics of the stimulation applied [4]. The TENS treatment is extensively preferred since it is safe, not expensive and has no side effects when compared to drug therapy [5].

TENS therapy is applied using clinical or portable type TENS devices and TENS electrodes. Metal plate electrodes covered by fabric tissue, carbon electrodes, and self-adhesive hydrogel electrodes are used as TENS electrodes up to this point [6]. The performance of these electrodes is very good. However, they are not hygienic because they are not washable and their sticky structure makes patients uncomfortable [7]. Furthermore, they are not suitable to be integrated into a smart garment. For these reasons, many type of research about textile electrodes is performing by researchers from all over the world recently. Most of the studies on textile electrodes focused on physiological monitoring and ECG, EMG and EEG measurements [8-15]. However, some of them concentrate on other fields such as electrical stimulation [16-20].

Prochazka et al. developed a functional electrical stimulation (FES) glove that improves hand function in people with spinal cord injury. The glove has conductive areas that contact with self-adhesive electrodes previously placed on the skin [21]. Lee et al. designed smart wear with built-in thermotherapy and TENS device for relief of dysmenorrhea [22]. Nisar et al. developed a rechargeable therapeutic wearable with embedded electrical stimulation device and skin adhesive electrodes for the prevention of pressure ulcers [23]. Keller et al. presented a transcutaneous electrical stimulation (TES) system consisted of a garment sleeve holding 60 textile embedded electrode pads and other electronic equipment. The developed system allows dynamic real-time adjustments of the electrode size and location for multiple regions on a single garment [24]. Li et al. designed and developed an intelligent garment with TENS function based on intarsia knitting technique. Silver conductive yarn was knitted into the garment to be used as electrodes and conducting wires [7]. Kim and Cho developed an e-textile-based smart glove with embedded textile electrodes. One side of the electrodes is a conductive snap which was used to combine with one end of a transmission line [16]. Goncu Berk presented the design process of a wearable pain management system with embroidered textile electrodes [25].

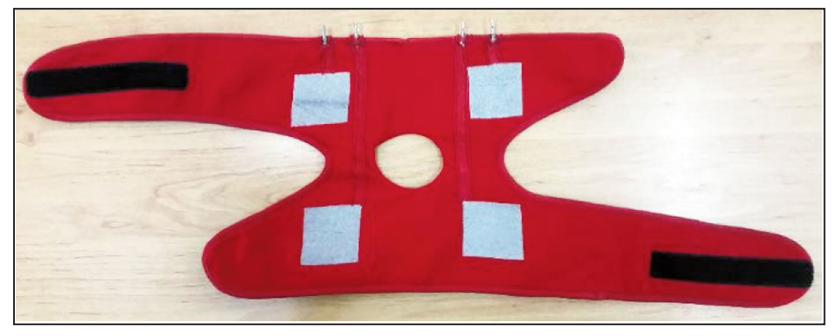

a
In this study, a knee pad with integrated electrodes and textile transmission lines have been designed and developed to be used for TENS therapy. Optimum electrode connections and electrode locations on the knee pad have been investigated. The electrical resistance values of textile electrodes and transmission lines which are integrated into the knee pad were measured. The developed knee pad was connected to a commercially available TENS device and electrical current transmission on subjects was tested. Furthermore, washing tests were conducted on knee pad and washing effect on textile electrodes and transmission lines were examined.

\section{MATERIAL AND METHOD}

\section{Sample production}

Knee pad is produced from two layers of $100 \%$ polyester laminated fabric with a weight of $150 \mathrm{~g} / \mathrm{m}^{2}$. Flame lamination of $1.7 \mathrm{~mm}$ thickness was applied to the base fabric with warp knitted fabric weighing $30 \mathrm{~g} / \mathrm{m}^{2}$. The raw material of the sponge used in lamination is polyurethane and its density is $26 \mathrm{~kg} / \mathrm{m}^{3}$. Since the bonding of the sponge to the fabric is done by melting the sponge in the flame machine, it is insoluble in the contact of the fabric with water. Electrodes and transmission lines were machine embroidered on one layer. The second fabric layer was used for providing a more aesthetical look. In this way, the sides of the electrodes which are not in contact with the skin and the transmission lines were concealed between two fabric layers. An empty area with $5 \mathrm{~cm}$ in diameter was formed on the patella to be used as a reference point for patients. The fabric layers were assembled using piping. Front and back views of the knee pad can be seen in figure 2 .

Totally four textile electrodes were embroidered on the knee pad. Electrode locations were chosen according to the opinions of physical therapy and rehabilitation experts and doctors and previous studies about this subject [2]. In TENS therapy, three different electrode localization methods are determined. The first one is to position the electrode on pain region or its surroundings. The second one is to position the electrode on dermatome regions which are related to pain and the last one is to position the electrode on some special points on human body like acupuncture or trigger points [2]. Based on these

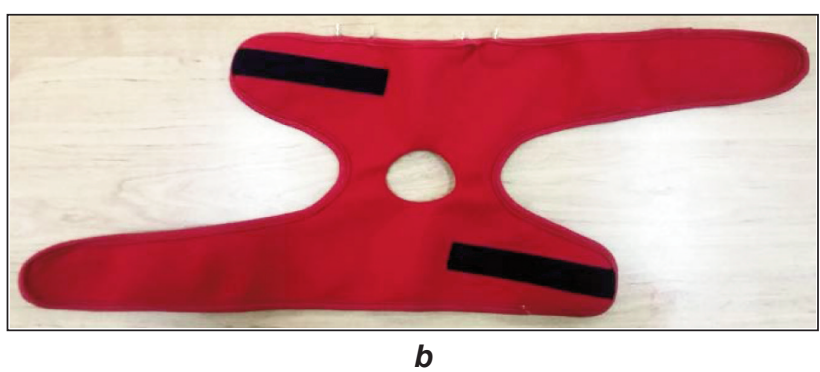

b

Fig. 2. Graphical presentations: $a$ - front view of knee pad; $b$ - back view of knee pad 
localization methods, patella was chosen as the center of the knee pad and electrodes were positioned on lower and upper corners. Electrodes, in size of $5 \mathrm{~cm} \times 5 \mathrm{~cm}$, and transmission lines, in sizes of $16 \mathrm{~cm} \times 0.5 \mathrm{~cm}$ and $3 \mathrm{~cm} \times 0.5 \mathrm{~cm}$, were directly machine embroidered on the fabric with Tajima TFGN embroidery machine. For a better conductivity, conductive yarns were preferred as both top thread and bobbin thread.

Two different conductive yarns (X-Silver and X-Static) were used for the production of conductive parts. Overlapped high-density patterns were used for the production of electrode regions and transmission lines based on previous studies [26, 27]. Transmission lines and electrodes were embroidered at once to prevent disconnections between electrodes and TENS device. Female banana plug connectors were used by being fastened to the one end of textile transmission lines. Connectors were $2.54 \mathrm{~cm}$ in diameter, noncorrosive, and commercially available products. Totally 2 knee pad samples were produced and tested.

\section{Testing of samples}

Since one of the main aims of this study is to develop an integrated and washable product, washing tests were applied to the knee pads for ten times. Washing tests were carried out using $4 \mathrm{~g} / \mathrm{lt}$ household detergent at $30^{\circ} \mathrm{C}$ main washing temperature in a domestic washing machine with reference to TS 5720 EN ISO 6330-2002 6A standard. After washing processes, samples were dried flat at room temperatures.

In order to evaluate the performance of textile electrodes and textile transmission lines, two different tests were applied. Firstly, electrical resistance values were measured before washing and after $1^{\text {st }}, 5^{\text {th }}$ and $10^{\text {th }}$ washing cycles with a Thurlby 1503 digital multimeter. Before the measurements, knee pad samples were conditioned for 24 hours in laboratory conditions with a relative humidity of $20 \pm 2^{\circ} \mathrm{C}$ and $65 \pm 2 \%$. Then, knee pad samples were connected to

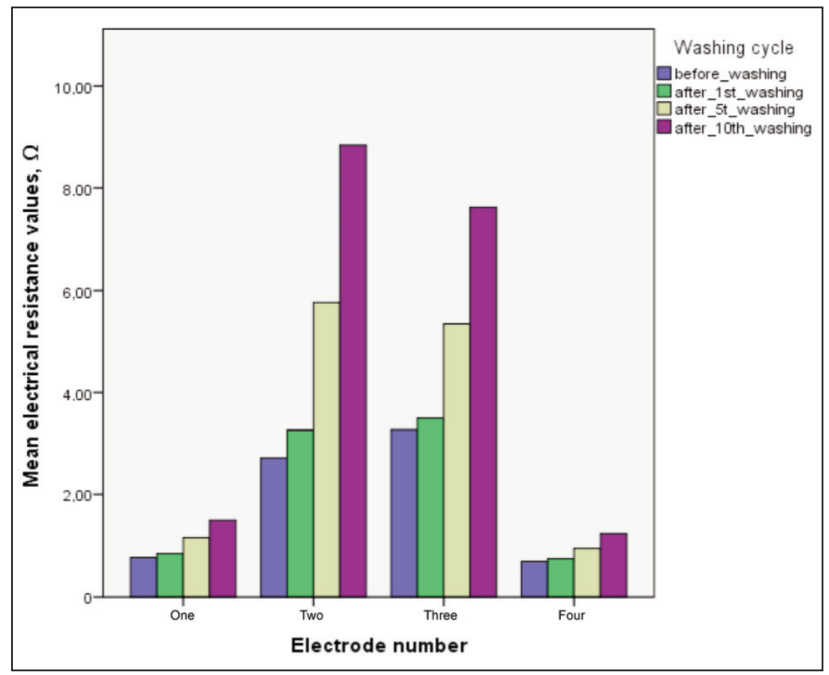

Fig. 3. Electrical resistance measurement results of knee pad produced using X-Silver yarn a Stimtec 2 model commercially available TENS device and current transmission was tested subjectively. Subjective trials were performed on 3 subjects ( 2 females, 1 male) which vary in ages from 28 to 52 , from 165 to $187 \mathrm{~cm}$ in length and from 60 to $88 \mathrm{~kg}$ in body weight. Volunteers do not have any health problems. Subjective trials were repeated before washing and after $1^{\text {st }}, 5^{\text {th }}$ and $10^{\text {th }}$ washings.

\section{RESULTS AND DISCUSSION}

The measured resistance values were evaluated with IBM SPSS Statistics 22 software and presented in figures 3 and 4 for knee pads produced using X-Silver and X-Static yarn, respectively. Electrical resistance values of electrodes and transmission lines were measured together and entitled as electrode number.

When figures 3 and 4 were examined, it is seen that electrical resistance values of the first and fourth electrodes are quite smaller when compared to second and third electrodes for both knee pads. The reason is that the first and fourth electrodes are located at the upper part of the knee pad and have shorter transmission lines, while other electrodes are located at the lower part and have longer transmission lines. All electrodes have the same dimensions and theoretically have the same electrical resistance values. Under these circumstances, it can be said that the difference between electrodes arises from the length of the transmission lines. An increase in the length of transmission lines causes an increase of electrical resistance values. When the figures are evaluated separately, it is observed that the electrical resistance values for the knee pad produced using X-Static yarn are higher especially electrodes with longer transmission lines.

When figures 3 and 4 were taken into consideration in the way of electrical resistance values before and after washing, it is observed that washing cycles give similar results for both knee pads. After washing processes, the electrical resistance values of electrodes and transmission lines are slightly increased. This

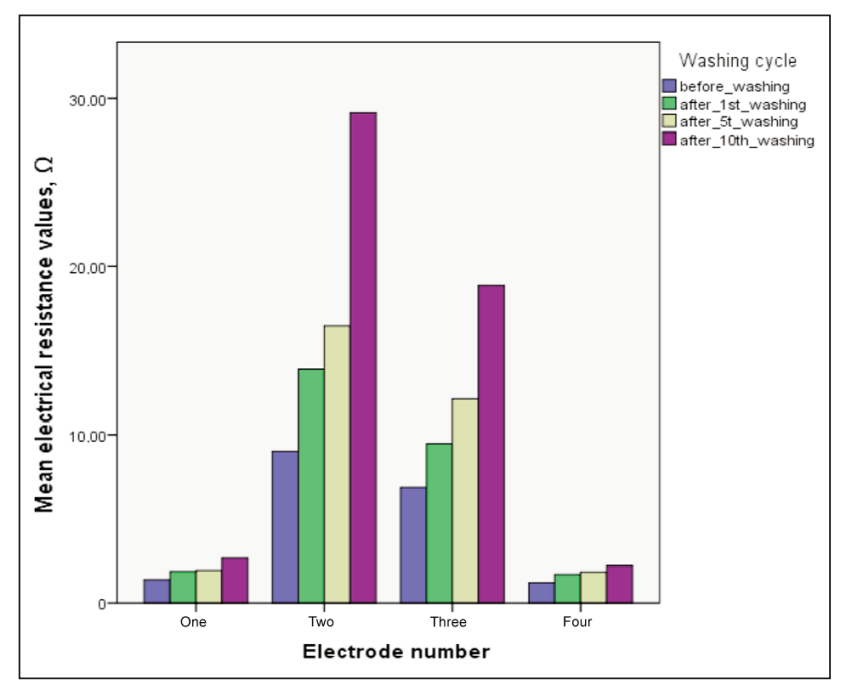

Fig. 4. Electrical resistance measurement results of knee pad produced using $X$-Static yarn 


\begin{tabular}{|c|c|c|c|c|c|c|c|c|}
\hline \multicolumn{9}{|c|}{ MEAN CURRENT TRANSMISSION RESULTS OF KNEE PAD USING X-SILVER YARN } \\
\hline Yarn type & \multicolumn{4}{|c|}{ X-Silver Yarn } & \multicolumn{4}{|c|}{ X-Static Yarn } \\
\hline Position & \multicolumn{2}{|c|}{ Sitting position } & \multicolumn{2}{|c|}{ Standing position } & \multicolumn{2}{|c|}{ Sitting position } & \multicolumn{2}{|c|}{ Standing position } \\
\hline Electrode type & $\begin{array}{c}\text { Upper } \\
\text { electrodes } \\
(\mathrm{mA})\end{array}$ & $\begin{array}{c}\text { Lower } \\
\text { electrodes } \\
(\mathrm{mA})\end{array}$ & $\begin{array}{c}\text { Upper } \\
\text { electrodes } \\
\text { (mA) }\end{array}$ & $\begin{array}{c}\text { Lower } \\
\text { electrodes } \\
(\mathrm{mA})\end{array}$ & $\begin{array}{c}\text { Upper } \\
\text { electrodes } \\
(\mathrm{mA})\end{array}$ & $\begin{array}{c}\text { Lower } \\
\text { electrodes } \\
(\mathrm{mA})\end{array}$ & \begin{tabular}{|c|} 
Upper \\
electrodes \\
$(\mathrm{mA})$
\end{tabular} & \begin{tabular}{|c} 
Lower \\
electrodes \\
(mA)
\end{tabular} \\
\hline Before washing & 4.8 & 5.2 & 3.2 & 3.6 & 3.2 & 3.2 & 4.2 & 4.0 \\
\hline After $1^{\text {st }}$ washing & 3.8 & 5.0 & 3.2 & 5.0 & 3.0 & 3.2 & 2.6 & 2.6 \\
\hline After $5^{\text {th }}$ washing & 6.0 & 2.8 & 2.8 & 4.2 & 2.2 & 3.2 & 2.8 & 2.6 \\
\hline After $10^{\text {th }}$ washing & 6.8 & 3.8 & 4.0 & 3.4 & 3.0 & 3.8 & 2.2 & 2.6 \\
\hline
\end{tabular}

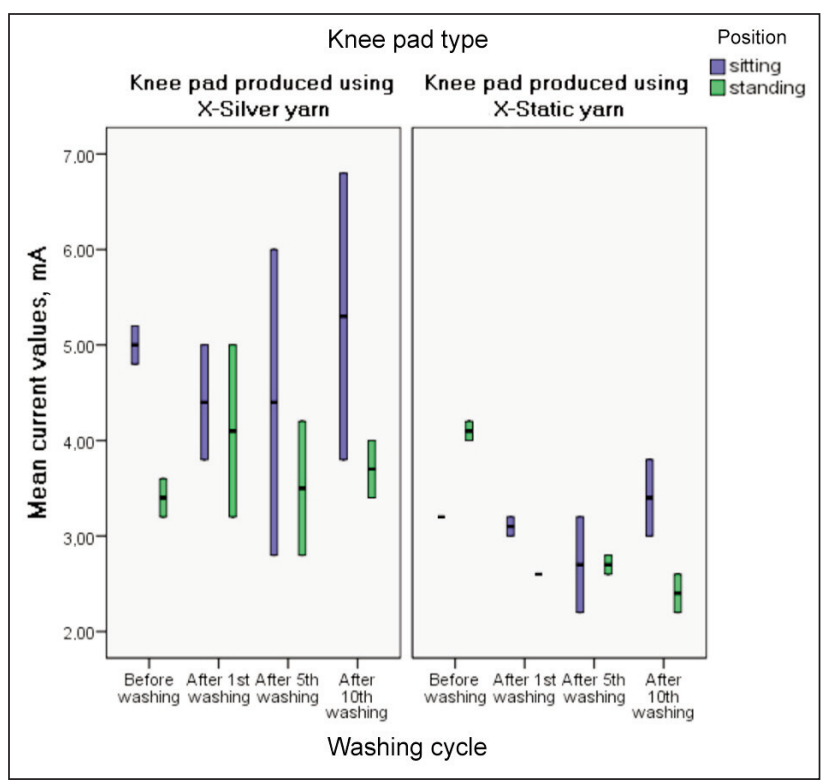

Fig. 5. Subjective trial results of knee pads

increase is followed by an increasing trend in direct proportion to the washing processes. It is concluded that after washing processes, the increase of electrical resistance values of longer lines is bigger than shorter lines.

In addition to electrical resistance measurements, subjective tests were also performed on the developed knee pads. The knee pads were connected to the StimTec brand TENS device and experiments were carried out while subjects were in standing and sitting positions. Subjective trials were repeated before washing and after $1^{\text {st }}, 5^{\text {th }}$ and $10^{\text {th }}$ washings. Mean current transmission results of subjective trials were presented in tables 1 and 2, general results were presented in figure 5 .

When table 1 and figure 5 were examined, it is seen that the mean current values of the knee pad produced using $X$-Static yarn distribute more homogeneously. This result shows that the entire electrodes and transmission lines of the knee pad produced using $\mathrm{X}$-Static yarn have similar electrical resistance values. Current values recorded in the experiments in standing position were lower than those recorded in sitting position for both knee pads. However, the difference is between 0 and $0.8 \mathrm{~mA}$ and it is negligible. According to these results, standing or sitting position does not affect current transmission.

\section{CONCLUSIONS}

In this paper, knee pads with integrated textile electrodes and textile transmission lines have been designed and produced for use in TENS therapy and the effectiveness of the knee pads have been investigated by preliminary tests. These preliminary tests were washing tests, electrical resistance measurement, and subjective trials. In preliminary work cables were used for electrical transmission, however, cables were broken especially after washing processes. In this study, textile transmission lines and banana plug connectors were used to solve this problem and products that are more resistant to washing processes were developed.

When electrical resistance measurements were taken into consideration, it is observed that different yarns cause different electrical resistance values. In our example, electrodes and transmission lines of knee pad produced using X-Static yarn have higher electrical resistance values than the knee pad produced using X-Silver yarn. Washing cycles give similar results for both knee pads. After washing processes, the electrical resistance values of electrodes and transmission lines are slightly increased.

In trials with TENS device and designed knee pads on the subjects, it is noted that subjects had electrical stimulation from knee pads. Also, according to these subjects' feedback, there is not any discomfort feeling. In consequence of first trials, it is concluded that produced knee pads can be used for pain relief and it is planned to test the effectiveness of knee pads on knee osteoarthritis patients after taking ethical committee permission. In this study only sitting and standing positions were examined, in further studies, it is planned to test the knee pad in a state of motion. Furthermore, in this study, only the effect of 10 washing cycles to electrical resistance values was examined. In further studies, it is planned to investigate the effect of more washing cycles and laundry processes. 


\section{REFERENCES}

[1] Sluka, K.A., Walsh, D., Transcutaneous electrical nerve stimulation: basic science mechanisms and clinical effectiveness, In: The Journal of Pain, 2003, 4, 3, 109-121

[2] Bélanger, A.Y., Kanıta dayalı elektroterapi, E. Yakut (ed.), Pelikan Yayınevi, 2008, Ankara, 43-76

[3] Melzack, R., Wall, P.D., Pain mechanisms: a new theory, In: Science, 1965, 150, 3699, 971-979

[4] Jette, D.U, Effect of different forms of transcutaneous electrical nerve stimulation on experimental pain, In: Physical Therapy, 1986, 66, 2, 187-190

[5] Jones, I., Johnson, M.I., Transcutaneous electrical nerve stimulation, In: Continuing Education in Anaesthesia, Critical Care \& Pain, 2009, 9, 4, 130-135

[6] Keller, T., Kuhn, A., Electrodes for transcutaneous (surface) electrical stimulation, In: Journal of Automatic Control, 2008, 18. 2, 35-45

[7] Li, L., Au, W.M., Li, Y., Wan, K.M., Wan, S.H., Wong, K.S., Design of intelligent garment with transcutaneous electrical nerve stimulation function based on the intarsia knitting technique, In: Textile Research Journal, 2010, 80, 3, 279-286

[8] Guo, L., Berglin, L., Wiklund, U., Mattila, H., Design of a garment-based sensing system for breathing monitoring, In: Textile Research Journal, 201, 83, 5, 499-509

[9] Kannaian, T., Neelaveni, R., Thilagavathi, G., Design and development of embroidered textile electrodes for continuous measurement of electrocardiogram signals, In: Journal of Industrial Textiles, 2013, 42, 3, 303-318

[10] Löfhede, J., Seoane, F., Thordstein, M., Textile electrodes for EEG recording - a pilot study, In: Sensors, 2012, 12, 12, 16907-16919

[11] Mestrovic, M.A., Helmer, R.J., Kyratzis, L., Kumar, D., Preliminary study of dry knitted fabric electrodes for physiological monitoring, In: Proceedings of 3rd International Conference on Intelligent Sensors Sensor Networks Information, Melbourne, Australia, 2007

[12] Paradiso, R., Loriga, G., Taccini, N., Gemignani, A., Ghelarducci, B., WEALTHY-a wearable healthcare system: new frontier on e-textile, In: Journal of Telecommunications and Information Technology, 2005, 4, 105-113

[13] Pola, T., Vanhala, J., Textile electrodes in ECG measurement, In: Proceedings of the 3rd International Conference on Intelligent Sensors, Sensor Networks and Information, Melbourne, Australia, 2007

[14] Rattfält, L., Lindén, M., Hult, P., Berglin, L., Ask, P., Electrical characteristics of conductive yarns and textile electrodes for medical applications, In: Medical \& Biological Engineering \& Computing, 2007, 45, 12, 1251-1257

[15] Song, H.Y., Lee, J.H., Kang, D., Cho, H., Cho, H. S., Lee, J.W., et.al., Textile electrodes of jacquard woven fabrics for biosignal measurement, In: The Journal of the Textile Institute, 2010, 101, 8, 758-770

[16] Kim, R.H., Cho, G., Effectiveness of the smart healthcare glove system for elderly persons with hypertension, In: Human Factors and Ergonomics in Manufacturing \& Service Industries, 2013, 23, 3, 198-212

[17] Zięba, J., Frydrysiak, M., Tokarska, M., Research of textile electrodes for electrotheraphy, In: Fibres \& Textiles in Eastern Europe, 2011, 5, 88, 70-74

[18] Gniotek, K., Frydrysiak, M., Zieba, J., Tokarska, M., Stempien, Z., Innovative textile electrodes for muscles electrostimulation, In: Proceedings of the 6th IEEE International Symposium on Medical Measurement and Applications, IEEE MeMeA, Bari, Italy, 2011

[19] Frydrysiak, M., Zięba, J., Tęsiorowski, L., Tokarska, M., Textronic system to muscle electrostimulation, In: International Scholarly and Scientific Research \& Innovation, 2012, 6, 11, 1311-1317

[20] Papaiordanidou, M., Takamatsu, S., Rezaei $\square$ Mazinani, S., Lonjaret, T., Martin, A., Ismailova, E., Cutaneous recording and stimulation of muscles using organic electronic textiles, In: Advanced Healthcare Materials, 2016, 5, 16, 2001-2006

[21] Prochazka, A., Gauthier, M., Wieler, M., Kenwell, Z., The bionic glove: an electrical stimulator garment that provides controlled grasp and hand opening in quadriplegia, In: Archives of physical medicine and rehabilitation, 1997, 78, 6, 608-614

[22] Lee, W. J., Um, S.H., R \& D of Smartwear built-in TENS device for relief of dysmenorrhea, In: The Research Journal of the Costume Culture, 2009, 17, 2, 320-329

[23] Nisar, H., Malik, A.R., Asawal, M., Cheema, H.M., An electrical stimulation based therapeutic wearable for pressure ulcer prevention, In: Proceedings of the IEEE EMBS Conference in Biomedical Engineering \& Sciences (IECBES), Kuala Lumpur, Malaysia

[24] Keller, T., Lawrence, M., Kuhn, A., Morari, M., New multi-channel transcutaneous electrical stimulation technology for rehabilitation, In: Proceedings of the International Conference of the IEEE Engineering in Medicine and Biology Society, New York, USA, 2006

[25] Goncu Berk, G., Design of a wearable pain management system with embroidered TENS electrodes, In: International Journal of Clothing Science and Technology, 2018, 30, 1, 38-48

[26] Erdem, D., Yesilpinar, S., Senol, Y., Karadibak, D., Akkan, T., Design of TENS electrodes using conductive yarn, In: International Journal of Clothing Science and Technology, 2016, 28, 3, 311-318

[27] Erdem, D., Yeşilpinar, S., Şenol, Y., Akkan, T., Karadibak, D., Design of TENS electrodes using different production techniques, In: Tekstilec, 2016, 59, 2, 132-136 
Authors:

\section{DUYGU ERDEM AKGÜN¹, SEVIL YEŞILPINAR², YAVUZ ŞENOL ${ }^{3}$}

1Selçuk University, Faculty of Architecture and Design, Fashion Design Department, Alaeddin Keykubat Campus, 42250, Konya, Turkey

2Dokuz Eylul University, Engineering Faculty, Textile Engineering Department, Tınaztepe Campus, 35370, Izmir, Turkey

e-mail: sevil.yesilpinar@deu.edu.tr

${ }^{3}$ Dokuz Eylul University, Engineering Faculty, Electrical and Electronics Engineering Department, Tınaztepe Campus, 35370, Izmir, Turkey

e-mail: yavuz.senol@deu.edu.tr

\section{Corresponding author:}

DUYGU ERDEM AKGÜN

e-mail: duygu.erdem@selcuk.edu.tr 